\title{
Meaning and Function of Sea Alms Ceremony for Coastal Communities Banyutowo Dukuhseti Pati
}

\author{
Laura Andri R.M.,S.S.,M.A.* Rahma Wulan S. \\ Departement of Indonesian Literature, Faculty of Humanities, Diponegoro University
}

\begin{abstract}
Sea alms ceremony is a ritual activity carried out once a year by the Banyutowo community. Banyutowo is one of the villages located in Dukuhseti District, Pati Regency. This traditional ceremony is carried out every month in Sura in the Javanese calendar. The sea alms has been going on for a long time and has become a strong cultural attraction. Sea alms for the coastal community of Banyutowo is not only about cultural rituals, but as a means of obtaining safety and maintaining natural balance. Aiming to express gratitude for the sustenance given by God Almighty, through this ceremony the Banyutowo community also requested safety in carrying out their daily work as fishermen so as not to get any interference. In addition, the values contained in marine charity include religious, social, economic and educational values. This tradition is believed to be a local tradition that cannot be eliminated. The focus of the study in this study is the meaning contained in the sea alms ceremony and its function for the surrounding community. The implementation of the research was carried out by applying qualitative research methods, through observation, documentary and indepth interviews with informants in Banyutowo. While the collected data was analyzed using descriptive, analysis and comparative methods. The results of this study are changes in the development of culture in sea alms rituals, both the process of carrying out rituals, meanings, and the function of the sea alms itself.
\end{abstract}

Keyword: ceremony, ritual, sea alms, meaning, function

\section{Background Research}

Sea alms ceremony is one of the rituals carried out by coastal communities, and generally such rituals are carried out by fishing communities, especially on the island of Java. In each region, these sea alms rituals have their own peculiarities, both naming and rituals are different.

In East Java, especially Lamongan, the fishing community called the sea alms ritual with Tutup Layang, in Madura the term sea alms is known as Rokatan, and in Banyuwangi it is better known as the Sea Pick. While the Banyutowo village community, Dukuhseti, Pati uses the term sea alms is slametan.

\footnotetext{
${ }^{*}$ Corresponding author : lauraandrirm01@gmail.com
} 
The sea alms ceremony is almost the same as nyadran, which is throwing away or melarung offerings in the middle of the sea. This ceremony is routinely carried out every year before or near the month of Sura or the first month of Javanese calculations. Sea alms is believed to have a function for its people. Generally it has a function of belief or religion, which is asking the Almighty God for the fishermen to be blessed with abundant marine products in the coming year and avoiding catastrophe during the sea.

In a fishing community, they have a strong belief in a socio-cultural belief. In carrying out their daily activities, they believe in the power of spirits, gods, and mythical creatures who guard the sea. This belief then forms a custom and cultural building which is then reflected in the ritual or ceremonial process in society, which describes the true character of the belief itself. This trust is carried out to establish positive relationships with spirits, both feared and respected spirits. This belief is done to establish good relations with spirits, both feared and respected.

Processing of sea alms ritual performed by the community is very conditional on ritualistic values, solemnity, and reverence. In addition, most sea alms rituals carried out by fishermen are expressions of feelings of inferiority in the presence of natural forces, especially the sea, because fishermen believe that the activities of fishermen in the sea are directly in contact with the forces behind human nature [1].

Another case with what happened in the Banyutowo community was through its sea alms tradition. In this area the community lives with various traditions and cultures that are synergistic with the diversity that exists. This can be seen from the lively tradition of sea alms ceremony held every year. Community confidence in myths gradually shifts towards realistic thinking. Although some fishing communities still adhere to the belief about the myths of sea alms which have a fundamental role in their lives. While other people have been able to interpret sea alms with more functional thoughts and realize that sea alms rituals have a wider function outside the mythological and ritualistic context. The mindset of an increasingly developing society, natural resources, and socio-cultural changes that occur in society have become factors that influence the development and changes in the form and function of sea alms rituals.

Formulation of the problem in the object of this research is, what meaning is contained in the sea alms ceremony for the people of Banyutowo Dukuhseti Pati and what functions are contained in the sea alms ritual. This research has theoretical benefits to contribute to the development of cultural knowledge about traditional ceremonies that exist in coastal communities. Practically, this research can be used to increase the understanding of readers who have an interest in the traditions and traditional culture of Indonesia, especially about the meaning and function of a sea alms ceremony.

\section{Method Research}

In the research conducted, the method used is a qualitative approach, using data collection techniques as follows:

a. Observation, carried out by looking directly at the object of research to find out and get more accurate and factual data.

b. Interviews, conducted by asking questions directly to the informant or the authority requested.

c. Literature study, carried out by collecting information from written sources about the object being published, as well as finding information directly or indirectly.

d. Documentation, research uses field research, with a sociological nature using qualitative research. The technique used is descriptive qualitative analysis with steps: (a) Selecting relevant data, (b) Making objective records, by classifying and editing (reducing), (c) Making reflective notes, (d) Concluding data, and (e) Triangulation, namely checking the 
correctness of data by concluding multiple data obtained through three ways: (1) extending the observation time in the field with the aim of matching the data that has been written with field data, (2) matching the data written with ask the informant again, and (3) match the data that has been written with the library source.

This research was conducted in Banyutowo village, Dukuhseti district, Pati Regency, for two weeks on 10-22 June 2019. Subject of this research is the sea alms ceremony performed by residents of Banyutowo village. The sample used in this study was the culture guard, leader of village, also residents of Banyutowo village.

\section{Literature Reference}

The traditional sea alms ceremony in village of Banyutowo means giving offerings to the rulers of the sea, namely God Almighty, as a form of thanksgiving and a request to obtain salvation. This sea alms ceremony is carried out by all citizens, whether working as fishermen or not.

Thiyas Tono Taufiq in his article entitled Religion-Based Environmental Wisdom of Fishermen Community in the Coast of Baanyutowo Dukuhseti Pati (2017) suggested that the environmental wisdom of the fishing community and coastal communities of Banyutowo was formed with the presence of social solidarity, sea alms rituals and other local traditions [2].

Endra Maelan's thesis from the State Islamic University of Sunan Kalijaga Yogyakarta entitled The Function of Sea Alms Ritual for the Gesing Gunung Kidul Beach Fishermen Society in the middle of the Social Change Flow Containing Sea Alms Rituals at Gesing beach which in its concept of root religiosity is an expression of the spirituality of the fishing community and has undergone a change of function [3].

The study written by Rini Iswari et al (2006), in his writing Study and Writing of Traditional Ceremonies in Cilacap District states the conditions of the Cilacap community in general, the history of Cilacap which is related to sea alms ceremonies, and sea alms ceremony processions [4].

Then the Javanese Traditional Ceremony, Explores the Strands of Local Wisdom. Books written by Purwadi (2005), in the book there are several studies on traditional Javanese ceremonies, one of which is the labuhan ceremony carried out by the Kemadang Village community on the Baron beach in Gunung Kidul Regency [5].

In this research will be different from previous research. This study emphasizes the ceremonial procession and the meaning and function of the sea alms for the people. And whether the tradition of sea alms in Banyutowo Dukuhseti Pati also experienced a shift in the function of sea alms rituals due to ongoing social changes.

\section{Result Research}

The tradition of sea alms is carried out every Javanese calculation, namely, the month of Sura on the 1st of each year and is located on the coast of Dukuhseti. The objects used for the tradition of sea alms are in the form of various kinds of offerings which have been determined by type and shape from generation to generation, carried out by the people of Banyutowo village, especially boat owners. The offerings will be disposed of in the water, precisely in the middle of the sea in the hope that they can be accepted as proof of the gratitude of fishermen to the rulers of nature for the fortune that has been bestowed on the people of Banyutowo. Along with the development of the times and changes in the social life of the sea alms tradition community experienced the development of form and function.

The change in the form of the sea alms tradition in Banyutowo lies in the form of its implementation, namely the determination of the Time and Place of the Sea Alms Tradition. 
At present, tradition does not always take place on 1 Sura, but the most important is still in the month of Sura. In addition, the place for carrying out the alms offerings of the sea alms tradition has also undergone changes, now it is no longer carried out in the middle of the sea but on land alone, precisely on the shore. After being prayed for, offerings must be distributed or eaten together by people who witness the sea charity program. This event was manifested as a sincere charity for charity.

In the past all prepared offerings would be thrown into the sea, but now only one main offer (sajen gedhe) has been used. Sajen gedhe is an offering made with the citizens of the community and a symbol of alms giving as a gift from the Banyutowo community. The community means sea alms ritual activities as a form of manifestation of gratitude to God Almighty.

Slametan tradition is held at night before the sea alms tradition, located on the beach of Banyutowo. This slametan is the main ceremony in a series of sea charity events. In addition to saying prayers, recitation sermons are also delivered in the sermon which aim to remind the Banyutowo community that the tradition of sea alms is one of the ways to preserve the cultural traditions of the community, as well as a means of strengthening community ties.

The Sea Alms ceremony is still believed by the Banyutowo community as a medium of "worship" that is related to life safety and prosperity. The more objects that are donated show the blessings that the charity will receive in the future. The more people who fight over alms offerings are believed to bring blessings to the giving alms. It is this attitude and mindset that actually makes people have a high mental solidarity, increasing concern for others so that they do not feel the loss of giving alms to others. In the past the tradition of marine alms functioned more as a means or medium to communicate itself with nature and inhabitants of the occult or ancestral spirits. However, now the function has undergone a shift. Sea alms serves to protect the lives of the fishermen in order to get the safety of life and prosperity. The sea alms ceremony through development and changes in functions including:

\subsection{Function of Entertainment, Communication, and Cultural Preservation}

Function of entertainment, in its development, sea almsgiving became a kind of people's party for the Banyutowo people in particular and the Dukuhseti people in general (secular function). Function of communication, gathering and togetherness between the community and the Pati Regency Government is a useful communication medium for the fishing community, as well as a forum to convey the problems faced by fishermen and hopefully a solution can be obtained. Function of cultural preservation, this preservation, through the process of transmitting or conveying cultural patterns from one generation to another, can occur intentionally and can also take place without realizing it. The function of ritual traditions is to sustain life and fulfill the need to maintain the social collectivity of the Dukuhseti community. Likewise, the mutual preservation of community traditions is well maintained.

\subsection{Function of Education and Economic Functions}

Function of education, Creativity, innovation, enculturation, and acculturation that occur during sea alms show that humans are active creatures. The role of the sea alms tradition for the community is spiritual education, work ethic education, education for fostering noble values, and education for the preservation of the natural environment. Economic function, Economically, the sea alms tradition is beneficial for large companies and small and medium enterprises to promote old products and new products. They opened a promotion and sales booth in the area where the marine service was held and there were even several companies that became sponsors. 


\section{Conclusion}

The tradition of sea alms in Banyutowo has undergone a change in shape with the development of implementation, namely changes in the form of offerings. This change occurs because it is influenced by the factors of social development and cultural development of the Banyutowo community that shape cultural creativity in the tradition of sea alms. The mindset of an increasingly developing society turned out to encourage development in the form of sea alms tradition. The change in the form of the sea alms tradition turns out to have a cultural function for the people. The development of the function of sea alms which is from the ritual function develops into a secular function.

\section{References}

1. A. Ismail, Agama Nelayan Pergumulan Islam dengan Budaya Lokal, Yogyakarta : Pustaka Pelajar, (2012)

2. T. Tono Taufik, "Kearifan Lingkungan Berbasis Agama (Studi Etnoekologi Komunitas Nelayan Di Pesisir Banyutowo Dukuhseti Pati)," Jurnal Sosiologi Agama, Vol. 11, No. 2, pp. 259-280, (2018)

3. E. Maelan, Fungsi Ritual Sedekah Laut bagi Masyarakat Nelayan Pantai Gesing Gunung Kidul di Tengah Arus Perubahan sosial, Yogyakarta : UIN Sunan Kalijaga, (2013)

4. R. Iswari, Pengkajian dan Penulisan Upacara Tradisional di Kabupaten Cilacap, Jakarta : Depdikbud, (2006)

5. Purwadi, Upacara Tradisional Jawa: Menggali Untaian Kearifan Lokal, Yogyakarta : Penerbit Pelajar, (2005)

6. Bagong, Suyanto \& Narwoko, J.D.(ed.), Sosiologi Teks Pengantar dan Terapan, Jakarta: Kencana (2007)

7. R. Bernard, Teori Sosiologi Modern. Jakarta : Prestasi Pustaka (2007)

8. S. Boedhisantoso, "Kesenian dan Kebudayaan," Makalah dalam Jurnal Wiled: Jurnal Seni, Edisi I Juli 1994, Surakarta : STSI (1994)

9. W.Giri, Sajen \& Ritual Orang Jawa, Yogyakarta : Narasi (2009)

10. Koentjaraningrat, Kebudayaan Jawa, Jakarta : Balai Pustaka (1994)

11. Maran, R. Rafael, Manusia dan Kebudayaan dalam Perspektif Ilmu Budaya Dasar, Jakarta : Rineka Cipta (2007)

12. S. McPherson, "National Agendas and Local Realities: Festive Material and Ritual Culture, Nationalism, and Modernity in the Chita Region of Japan," Artikel dalam Jurnal Cross-Currents: East Asian History and Culture Review, US : University of Hawaii Press (2012)

13. J. Robbins, "Ritual Pluralism and Value Pluralism: On Why One Ritual is Never Enough," Artikel dalam Jurnal Soumen Antropologi. Finlandia : Suomen Antropologinen Seura (Finnish Anthropological Society) (2017)

14. Setiadi, dkk, Ilmu Sosial dan Budaya Dasar, Jakarta : Kencana (2009)

15. T. Sumaryanto, Pendekatan Kuantitatif dan Kualitatif: Dalam Penelitian Pendidikan Seni. Semarang : UNNES Press. (2007)

16. Suseno, Magnis. Franz. Etika Jawa. Jakarta: Gramedia. (1985) 